\title{
THE HISTOLOGY OF CAMBRO-ORDOVICIAN VERTEBRATES
}

SANSOM*, Ivan J., School of Earth Sciences, University of Birmingham, Edgbaston, Birmingham B15 2TT, UK; SMITH, M. Paul, School of Earth Sciences, University of Birmingham, Edgbaston, Birmingham B15 2TT, UK; SMITH, Moya M., Department of Anatomy and Cell Biology, UMDS Guy's Hospital, London SE1 9RT, UK.

The past fifteen years has seen the publication of a number of papers on the phylogeny and paleobiology of primitive vertebrates. Data from these studies has greatly increased our knowledge of the whole body anatomy and diversity of the vertebrates that swam in Ordovician seas. One approach has been to concentrate on the histology and morphology of microvertebrate remains.

The superb histological preservation of the Harding Sandstone (basal Franklinian, Ordovician) of Colorado has enabled a detailed comparison of the hard tissues in both conodont elements and fish scales, and the identification of numerous dentine types in conodont basal bodies and tubercles of dermal armour. This comparative study has significantly increased the range of vertebrate hard tissues which form conodont elements, building on the preliminary study of Sansom et al. (1992). Conodont elements have basal bodies formed from a wide variety of tissues, including tubular and atubular forms of dentine or cartilage, the lamellar crown is formed from an enamel homologue (in some conodonts this tissue is indistinguishable from tetrapod enamel), whilst white matter is best described as a cellular bone-like tissue. The identification of vertebrate hard tissues in conodonts has allowed us to produce a new growth model for hyaline conodont elements, and work is continuing to develop a similar model for the construction of albid elements.

Until recently, it was widely believed that only three vertebrate taxa were present in the Harding Sandstone. A further conclusion from our studies is that the vertebrate diversity, even when conodonts are excluded, has been greatly underestimated. In addition to the common heterostracomorph genera Astraspis and Eriptychius, described by Walcott (1892), other major groups are also present, including thelodonts, sharks and possible acanthodians. A major evolutionary episode took place amongst vertebrates during the Late Cambrian to Middle Ordovician with Anatolepis, from the Late Cambrian of North America, and conodonts representing the approximately synchronous first appearance of the clade.

SANSOM, I. J., M. P. SMITH, H. A. ARMSTRONG, AND M. M. SMTTH. 1992. Presence of the earliest vertebrate hard tissues in conodonts. Science, 256: 1308-1311.

WALCOTT, C.D. 1892. Preliminary notes on the discovery of a vertebrate fauna in Silurian

(Ordovician) strata. Bulletin of the Geological Society of America, 3, 153-171. 